\title{
HIGH STEP-UP DC-DC CONVERTER FOR AC PHOTOVOLTAIC MODULE WITH MPPT CONTROL
}

\author{
Govindasamy Sundar* — Narashiman Karthick* \\ - Sasi Rama Reddy ${ }^{* *}$
}

\begin{abstract}
This paper presents the high gain step-up BOOST converter which is essential to step up the low output voltage from PV panel to the high voltage according to the requirement of the application. In this paper a high gain BOOST converter with coupled inductor technique is proposed with the MPPT control. Without extreme duty ratios and the numerous turns-ratios of a coupled inductor this converter achieves a high step-up voltage-conversion ratio and the leakage energy of the coupled inductor is efficiently recycled to the load. MPPT control used to extract the maximum power from PV panel by controlling the Duty ratio of the converter. The PV panel, BOOST converter and the MPPT are modeled using Sim Power System blocks in MATLAB/SIMULINK environment. The prototype model of the proposed converter has been implemented with the maximum measured efficiency is up to $95.4 \%$ and full-load efficiency is $93.1 \%$.
\end{abstract}

K e y w or d s: PV panel, boost converter, coupled inductor, MPPT control

\section{INTRODUCTION}

Photo-voltaic power generation is becoming commercial success across worldwide. So that a high step-up BOOST converter is essential to step up the low voltage from photo-voltaic panel to high voltage as required by the applications (load or grid). Researchers are round the clock to develop better BOOST converter with MPPT and efficient control mechanism. The challenge of the project and the new area of study were the motivations behind the project.

Photovoltaic (PV) power-generation systems are becoming increasingly important and prevalent in distribution generation systems. A conventional centralized PV array is a serial connection of numerous panels to obtain higher dc-link voltage for main electricity through a dcac inverter. Unfortunately, once there is a partial shadow on some panels, the system's energy yield becomes significantly reduced. The power capacity range of a single $\mathrm{PV}$ panel is about $100 \mathrm{~W}$ to $300 \mathrm{~W}$, and the maximum power point (MPP) voltage range is from $15 \mathrm{~V}$ to $40 \mathrm{~V}$, which will be the input voltage of the ac module; in cases with lower input voltage, it is difficult for the ac module to reach high efficiency. However, employing a high stepup dc-dc converter in the front of the inverter improves power-conversion efficiency and provides a stable dc link to the inverter. Fig. 1. Shows in the block diagram.

The dc-dc converter requires large step-up conversion from the panel's low voltage to the voltage level of the application. The control circuit comprises of MPPT to extract maximum power from PV-panel, Thus the Perturb and Observe (P,O) MPPT method is used to control the duty ratio of BOOST converter due to which the PV panel operates at MPP and high power conversion ratio is achieved. Hence high efficiency of the converter is obtained.

Earlier, various converters for high step-up applications has included analyses of the switched-inductor and switched-capacitor types [5]; ultra gain switchedcapacitor type [1]; and the boost type integrated with sepic converter [3], these converters by increasing turns ratio of coupled inductor obtain higher voltage gain than conventional boost converter. Some converters successfully combined boost converters with coupled inductor, since various converter combinations are developed to carry out high step-up voltage gain by using the coupledinductor technique [1-7]. The efficiency and voltage gain of the $\mathrm{dc}-\mathrm{dc}$ boost converter are constrained by either the parasitic effect of the power switches or the reverse recovery issue of the diodes. In addition, the equivalent series resistance (ESR) of the capacitor and the parasitic resistances of the inductor also affect overall efficiency.

The modeling of PV panel and the MPPT control is presented in [8-16]. The proposed converter attains high gain by efficiently utilizing the coupled inductor and recycling the leakage inductors energy and MPPT controls the duty ratio of the BOOST converter to extract the maximum power from PV panel.

High gain is attained in continuous conduction mode (CCM) operation in [5]. So the proposed converter is analyised in CCM mode.

\section{PROPOSED BOOST CONVERTER}

The proposed BOOST converter has a coupled inductor with floating active switch is used to attain high gain and high power conversion ratio and also to achieve high

\footnotetext{
* Arulmigu Meenakshi Amman College of Engineering, Vadamavandal, Kanchipuram, 604 410, sund_geee@yahoo.co.in, India ** Electrical Department Jerusalem Engineering College, Chennai, India
} 


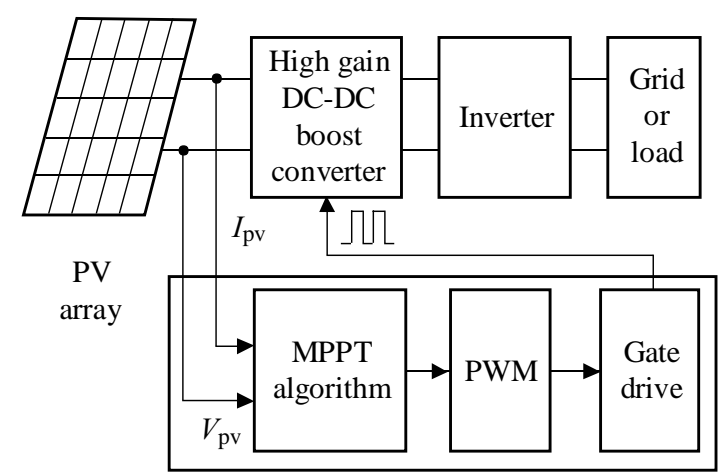

Fig. 1. A structure of BOOST converter with PV panel and MPPT control

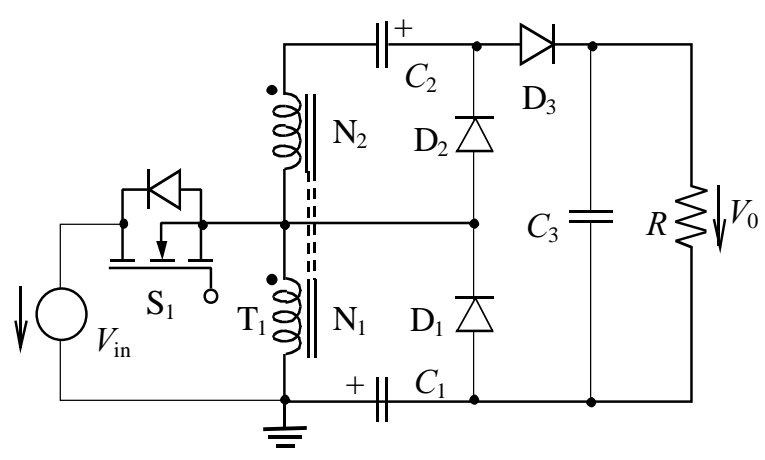

Fig. 2. Circuit configuration of proposed converter

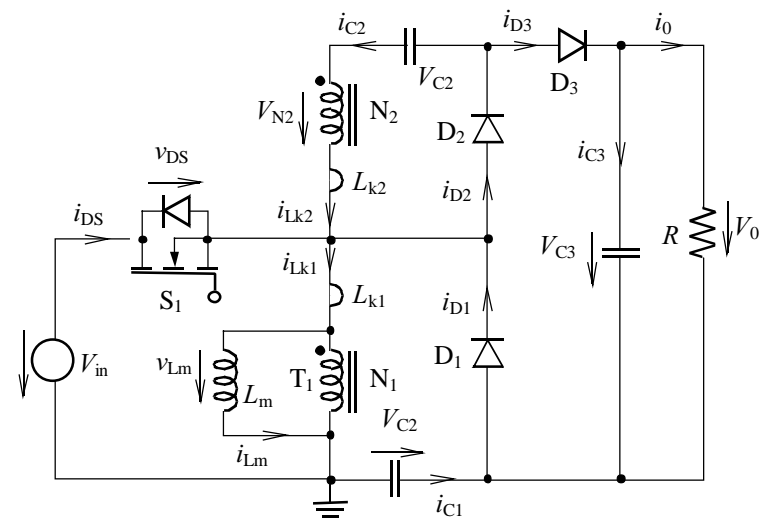

Fig. 3. Polarity definitions of voltage and current in proposed converter

efficiency without switching stress and power loss is proposed.

The proposed converter, shown in Fig. 2, is comprised of a coupled inductor $T_{1}$ with the floating active switch $S_{1}$. The primary winding $N_{1}$ of a coupled inductor $T_{1}$ is similar to the input inductor of the conventional boost converter, and capacitor $C_{1}$ and diode $D_{1}$ receive leakage inductor energy from $N_{1}$. The secondary winding $N_{2}$ of coupled inductor $T_{1}$ is connected with another pair of capacitors $C_{2}$ and diode $D_{2}$, which are in series with $N_{1}$ in order to further enlarge the boost voltage. The rectifier diode $D_{3}$ connects to its output capacitor $C_{3}$. The proposed converter has several features: 1) The connection of the two pairs of inductors, capacitor, and diode gives a large step-up voltage-conversion ratio; 2) the leakageinductor energy of the coupled inductor can be recycled, thus increasing the efficiency and restraining the voltage stress across the active switch; and 3) the floating active switch efficiently isolates the PV panel energy during nonoperating conditions, which enhances safety.

The simplified circuit model of the proposed converter is shown in Fig. 3. The coupled inductor $T_{1}$ is represented as a magnetizing inductor $L_{m}$, primary and secondary leakage inductors $L_{k 1}$ and $L_{k 2}$, and an ideal transformer. In order to simplify the circuit analysis of the proposed converter, the following assumptions are made.

1) All components are ideal, except for the leakage inductance of coupled inductor $T_{1}$, which is being taken under consideration. The on-state resistance $R_{\mathrm{DS}(\mathrm{ON})}$ and all parasitic capacitances of themain switch $S_{1}$ are neglected, as are the forward voltage drops of diodes $D_{1} \sim D_{3}$.

2) The capacitors $C_{1} \sim C_{3}$ are sufficiently large that the voltages across them are considered to be constant.

3) The ESR of capacitors $C_{1} \sim C_{3}$ and the parasitic resistance of coupled inductor $T_{1}$ are neglected.

4) The turns ratio $n$ of the coupled inductor $T_{1}$ windings is equal to $N_{2} / N_{1}$.

The operating principle is analysied only in continuous conduction mode (CCM) because high gain of the proposed converter is achieved in CCM and its operation is presented in detail. Fig. 4. Shows the waveforms of BOOST converter in CCM operation. The operating modes are described as follows.

\subsection{Charging Mode}

In this mode of operation; the switch is closed and the inductor is charged by the source through the switch. The charging current is exponential in nature but for simplicity is assumed to be linearly varying. The diode restricts the flow of current from the source to the load and the demand of the load is met by the discharging of the capacitor.

\subsection{Discharging Mode}

In this mode of operation; the switch is open and the diode is forward biased. The inductor now discharges and together with the source charges the capacitor and meets the load demands. The load current variation is very small and in many cases is assumed constant throughout the operation.

\section{PV CELL MODELING}

A solar PV cell is the building block of a solar panel. A photovoltaic module is formed by connecting many solar cells in series and parallel. Series connections are responsible for increasing the voltage of the module whereas the 

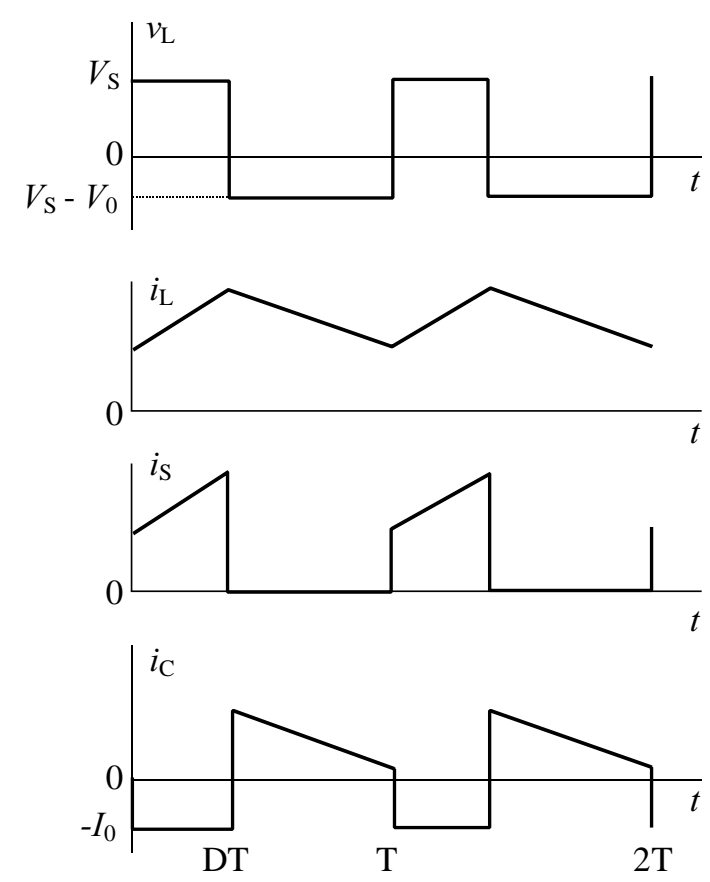

Fig. 4. Waveforms of boost converter

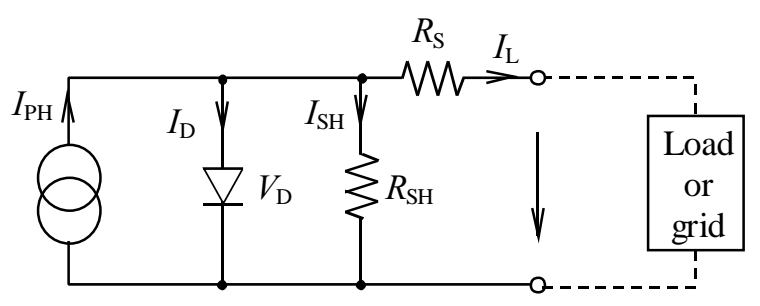

Fig. 5. Single diode model of a solar cell

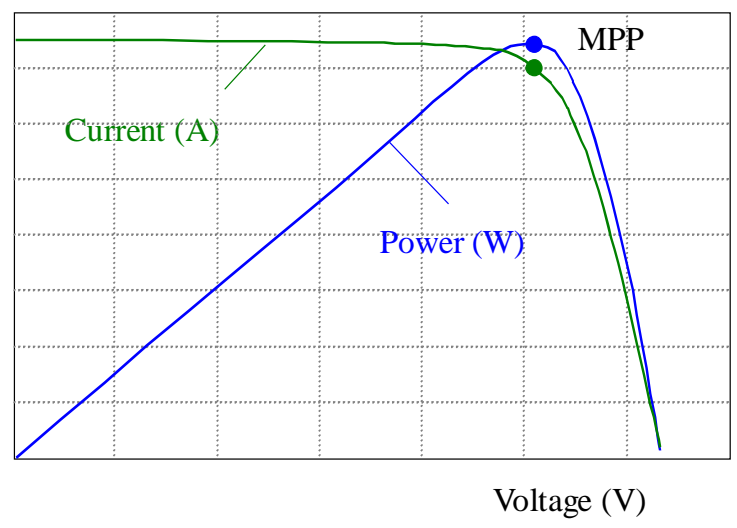

Fig. 6. $P-V I-V$ curve of a solar cell

parallel connection is responsible for increasing the current in the array. Considering only a single solar cell; it can be modeled by utilizing a current source, a diode and two resistors. This model is known as a single diode model of solar cell. Two diode models are also available but only single diode model is considered here $[8,12,14]$.

In this model we consider a current source $(I)$ along with a diode and series resistance $\left(R_{s}\right)$. The shunt resistance (RSH) in parallel is very high, has a negligible effect and can be neglected. The output current from the photovoltaic array is

$$
I=I_{s c}-I_{d}
$$

where

$$
I_{d}=I_{o}\left(e q V_{d} / k T-1\right)
$$

where $I_{o}$ is the reverse saturation current of the diode, $q$ is the electron charge, $V_{d}$ is the voltage across the diode, $k$ is Boltzmann constant $\left(1.38 \times 10^{-19} \mathrm{~J} / \mathrm{K}\right)$ and $T$ is the junction temperature in Kelvin (K).

From (1) and (2)

$$
I=I_{s c}-I_{o}(e q V d / k T-1) .
$$

Using suitable approximations

$$
I=I_{s c}-I_{o}(e q((V+I R s) / n k T)-1)
$$

where $I$ is the photovoltaic cell current, $V$ is the PV cell voltage, $T$ is the temperature (in Kelvin) and $n$ is the diode ideality factor.

The $I-V$ and $P-V$ curves for a solar cell are given in the following figure. It can be seen that the cell operates as a constant current source at low values of operating voltages and a constant voltage source at low values of operating current. Solar cells are current source which produces the flow of electrons due to photo effect and produces the potential difference. Figure 6 shows the $P-$ $V$ and $I-V$ curve.

\section{MPPT CONTROL ALGORITHM}

A typical solar panel converts only 30 to 40 percent of the incident solar irradiation into electrical energy. Maximum power point tracking technique is used to improve the efficiency of the solar panel.

According to Maximum Power Transfer theorem, the power output of a circuit is maximum when the Thevenin impedance of the circuit (source impedance) matches with the load impedance. Hence our problem of tracking the maximum power point reduces to an impedance matching problem.

In the source side we are using a boost convertor connected to a solar panel in order to enhance the output voltage so that it can be used for different applications like motor load. By changing the duty cycle of the boost converter appropriately we can match the source impedance with that of the load impedance. The various MPPT techniques are discussed in $[9-11,13,15,16]$.

There are many methods used for maximum power point tracking a few are listed below:

- Perturb and Observe method

- Incremental Conductance method

- Current sweep method

- Constant Voltage method 


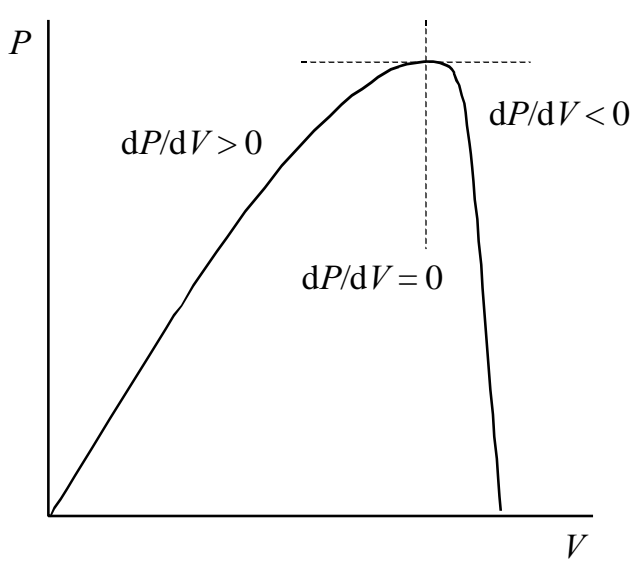

Fig. 7. P-V Characteristics of a solar cell

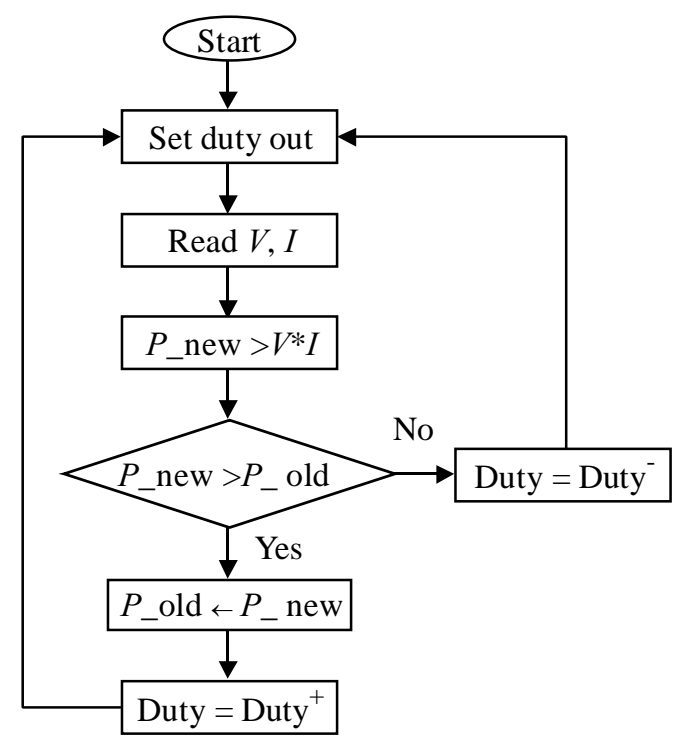

Fig. 8. Flow chart of perturb \& observe MPPT

\section{- Constant Current method}

Thus from the above methods perturb and observe $(\mathrm{P} \& \mathrm{O})$ method is the most frequently used algorithm to track the maximum power due to its simple structure and fewer required parameters. So, our analysis is only focused on $\mathrm{P} \& \mathrm{O}$ MPPT method. We use only this technique to track the maximum power point.

This method is the most common. In this method very less number of sensors are utilized. The operating voltage is sampled and the algorithm changes the operating voltage in the required direction and samples $\mathrm{d} P / \mathrm{d} V$. If $\mathrm{d} P / \mathrm{d} V$ is positive, then the algorithm increases the voltage value towards the MPP until $\mathrm{d} P / \mathrm{d} V$ is negative. This iteration is continued until the algorithm finally reaches the MPP. Thus the characteristic $P V$ panel power curve is shown in Fig. 7. Thus by perturb and observe method MPP is reached.

The basic operating procedure of $\mathrm{P} \& \mathrm{O}$ method. In a fixed period of time, the load of the $P V$ system is adjusted in order to change the terminal voltage and output power of the $P V$ modules.
The variations of the output voltage and power before and after changes are then observed and compared to reference for increasing or decreasing the load in the next step. If the perturbation in this time results in greater output power of $P V$ modules than that before the variation, the output voltage of $P V$ modules will be varied toward the same direction. Otherwise, if the output power of $P V$ modules is less than that before variation, it indicates that the varying direction in the next step should be changed. The maximum output power point of a $P V$ system can be obtained by using these iterative perturbation, observation and comparison steps. The advantages of the $\mathrm{P} \& \mathrm{O}$ method are simple structure, easy implementation and less required parameters.

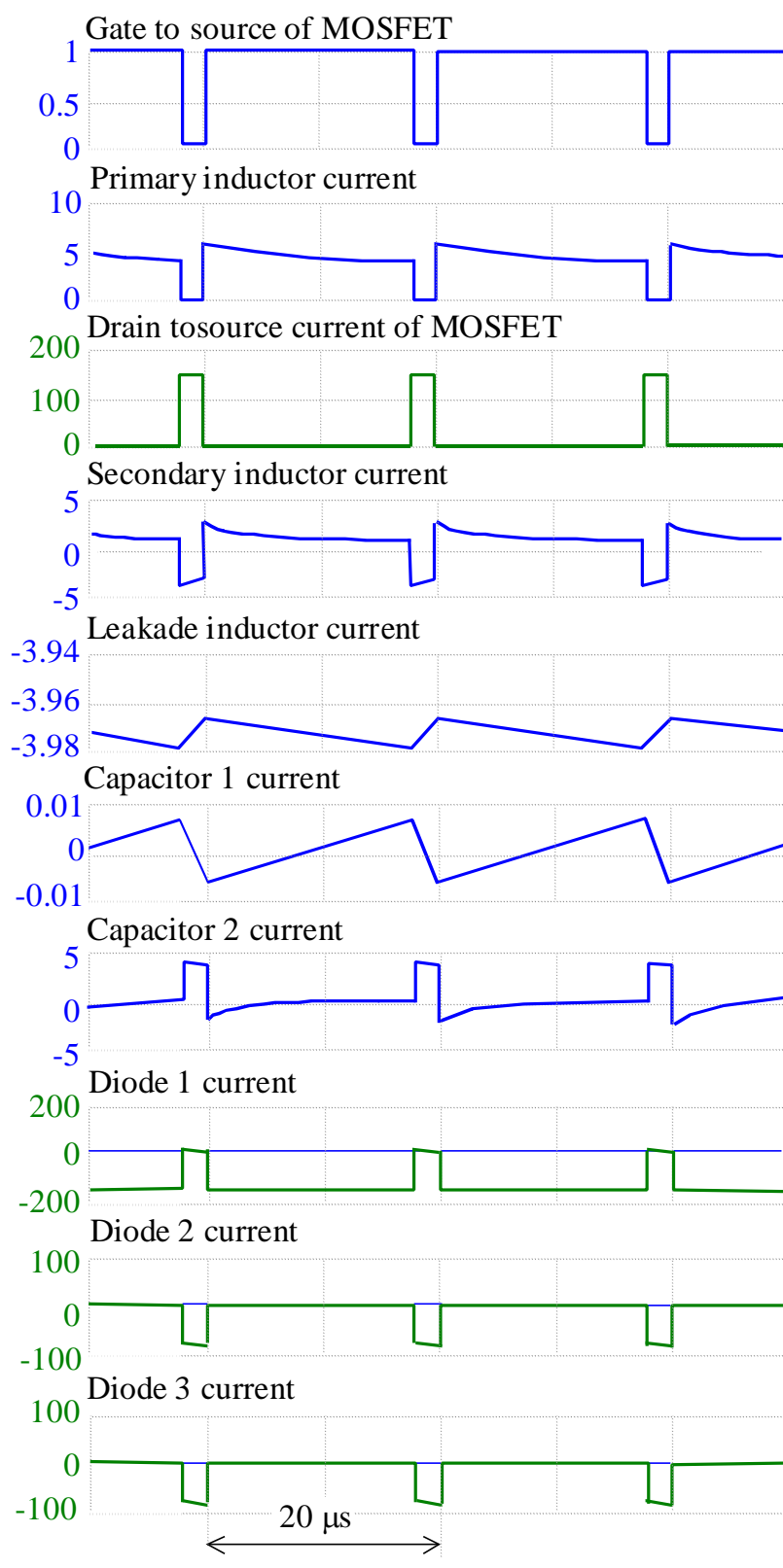

Fig. 9. Experimental waveforms measured at the test condition

The flowchart of perturb and observe (P\&O) method MPPT algorithm is shown as Fig. 8. The MPP tracker 
Table 1. Ouput Voltage obtained from PV Panel at Standard Test Conditions

\begin{tabular}{cccccc}
\hline $\begin{array}{c}\text { Sample } \\
\text { No. }\end{array}$ & PV panel type $\begin{array}{c}\text { Insolation } \\
\text { level at test } \\
\left(\mathrm{kW} / \mathrm{m}^{2}\right)\end{array}$ & $\begin{array}{c}\text { Voltage } \\
\text { rating } \\
(\mathrm{V})\end{array}$ & $\begin{array}{c}\text { Current } \\
\text { rating } \\
(\mathrm{A})\end{array}$ & $\begin{array}{c}\text { Output voltage } \\
\text { of PV panel } \\
(\mathrm{V})\end{array}$ \\
\hline 1 & $\begin{array}{c}\text { Monocrystaline } \\
\text { Silicon panel }\end{array}$ & 1000 & 20 & 4.45 & $38-40$ \\
& $\begin{array}{c}\text { Monocrystaline } \\
\text { Silicon panel }\end{array}$ & & & & \\
\hline
\end{tabular}

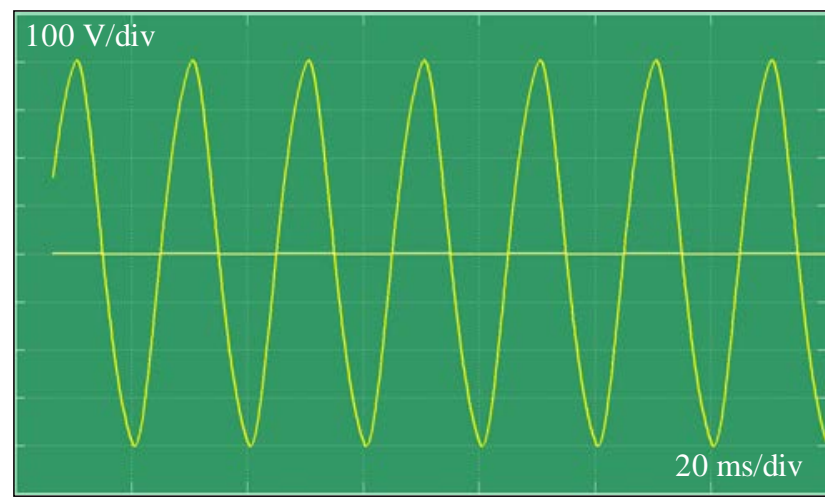

Fig. 10. Output voltage from proposed BOOST converter

operates by periodically incrementing or decrementing the solar array voltage. If a given perturbation leads to an increase (decrease) the output power of the PV, then the subsequent perturbation is generated in the same (opposite) direction. In Fig. 8, set Duty out denotes the perturbation of the solar array voltage, and Duty ${ }^{+}$and Duty- ${ }^{-}$represent the subsequent perturbation in the same or opposite direction, respectively.

In $\mathrm{P} \& \mathrm{O}$ method the voltage and current values is obtained from PV panel and these values are used to control the Duty ratio (D) of the BOOST converter to extract maximum power from the PV panel. The value of $\mathrm{d} P / \mathrm{d} V$ is incremented and decremented by controlling the Duty ratio of the BOOST converter MOSFET switch in order to operate at MPP and to attain the high voltage gain.

\section{SIMULATION RESULTS}

A $100 \mathrm{~W}$ prototype sample is presented to verify the practicability of the proposed BOOST converter. The electrical specifications are Input voltage $=10 \mathrm{~V}$, Output voltage $=140-150 \mathrm{~V}, f_{S}=50 \mathrm{kHz}$, and full-load resistance $R=400 \Omega$. The major components required are $C_{1}=C_{2}=47 \mu \mathrm{F}$ and $C_{3}=220 \mu \mathrm{F}$. The turns ratio $n=5$, the duty ratio $D$ is derived as $55 \%$.

The actual inductance of magnetizing inductor $L_{m}$ of the coupled inductor is $30.54 \mu \mathrm{H}$, which is larger than boundary magnetizing inductance $24.75 \mu \mathrm{H}$. Figure 10 shows voltage and current waveforms, which are measured from active switch $S_{1}$, diodes $D_{1}, D_{2}$, and $D_{3}$, and the current waveforms of $C_{1}$ and $C_{2}$.

The PV panel is connected to supply the proposed BOOST converter the high gain and high voltage conversion is obtained around 10-15 times increase from the PV panel low voltage to the high voltage required by the application.

Output from the PV panel is obtained by connecting two $20 \mathrm{~V}$ panel in series to obtain $40 \mathrm{~V}$, as presented in Tab.1.

The output of $40 \mathrm{~V}$ from PV panel is given as input to the proposed BOOST converter which is stepped-up to $380-400 \mathrm{~V}$ given to load or grid is shown in Fig. 10.

The equivalent circuit of $\mathrm{PV}$ panel is used for its simulation, proposed BOOST converter is simulated using the blocks, MPPT control is simulated from its flowchart.

The PV panel, proposed BOOST converter and perturb and observe method MPPT is simulated in MATLAB/SIMULINK using Powerlib and Sim power system blocks.

\section{CONCLUSION}

A High step-up BOOST converter with MPPT control is presented. It achieves a high step-up voltage gain. Since the energy of the coupled inductor's leakage inductor has been recycled, the voltage stress across the active switch $S_{1}$ is constrained. Thus, improvements to the efficiency of the proposed converter have been achieved. Using MPPT maximum power is extracted from PV panel and the Duty ratio of the BOOST converter is efficiently controlled by MPPT. From the prototype converter, the turns ratio $n=5$ and the duty ratio $D$ is $55 \%$. Thus, without extreme duty ratios and turns ratios, the proposed converter achieves high step-up voltage gain, of up to 13 times the level of input voltage. The residential energy is effectively eliminated during the non-operating condition, which enhance the safety and protect the system and technicians. The simulation result of a $40 \mathrm{~V}$ input voltage (from PV panel) to $380-400 \mathrm{~V}$ output voltage is obtained by using MATLAB/SIMULINK environment. The experimental results show that the maximum efficiency is up to $95.4 \%$. 


\section{REFERENCES}

[1] LIANG, T. J.-CHEN, S. M.-YANG, L. S.-CHEN, J. F.IOINOVICI, A. : Ultra Large Gain Step-Up Switched-Capacitor dc-dc Converter with Coupled Inductor for Alternative Sources of Energy, IEEE Trans. Circuits Syst. 59 No. 4 (Apr 2012).

[2] WAI, R. J.-LIN, C. Y.-RDUAN,. Y.-CHANG, Y. R.: High-Efficiency dc-dc Converter with High Voltage Gain and Reduced Switch Stress, IEEE Trans. Ind. Electron. 54 No. 1 (Feb 2007), 354-364.

[3] PARK, K. B.-MOON, G. W.-YOUN, M. J. : Nonisolated High Step-Up Boost Converter Integrated with Sepic Converter, IEEE Trans. Power Electron. 25 No. 9 (Sep 2010), 2266-2275.

[4] ZHAO, Q.-LEE, F. C.: High-Efficiency, High Step-Up dc-dc Converters, IEEE Trans. Power Electron. 18 No. 1 (Jan 2003), $65-73$.

[5] HAN, J.-JOUAnNe, A. V.-TEMES, G. C.: A New Approach to Reducing Output Ripple in Switched-Capacitor-Based Step-Down dc-dc Converters, IEEE Trans. Power Electron. 21 No. 6 (Nov 2006).

[6] YAO, G.-CHEN, A.-HE, X. : Soft Switching Circuit for Interleaved Boost Converters, IEEE Trans. Power Electron. 22 No. 1 (Jan 2007), 80-86.

[7] CHEN, S. M.-LIANG, T. J.-YANG, L. S.-CHEN, J. F. : A Cascaded High Step-Up dc-dc Converter with Single Switch for Microsource Applications jour IEEE Trans. Power Electron..

[8] Bernardo, P. C. M.-PEIXOTO, Z. M. A.-MACHADO NETO, L. V. B. : A High Efficient Micro-Controlled Buck Converter with Maximum Power Point Tracking for Photovoltaic Systemsinbook ICREPQ 09., Valencia-Spain.

[9] KUMARI, J. S.-BABU, C. S.: Comparison of Maximum Power Point Tracking Algorithms for Photovoltaic System, IJAET.

[10] YU, T. C.-LIN, Y. C.: A Study on Maximum Power Point Tracking Algorithms for Photovoltaic Systems, Lunghwa University of Science and Technology, Dept. of Electrical Engineering.

[11] JIANG, J. A.-HUANG, T. L.-HSIAO, Y. T.-CHEN, C. H. : Maximum Power Tracking for Photovoltaic Power Systems, Tamkang Journal of Science and Engineering 8 No. 2 (2005), $147-153$.

[12] ABDUlKadiR, M.-SAMOSIR, A. S.-YATIM, A. H. M.: Modeling and Simulation based Approach of Photovoltaic System in Simulink Model, ARPN Journal of Engineering and Applied Sciences 7 No. 5 (May 2012).

[13] SALHI, M.-El-BACHTIRI, R.: A Maximum Power Point Tracking Photovoltaic System using a Proportional Integral Regulator, SATRESET 1 No. 2 (June 2011).
[14] PANWARA, S.-SAINI, R. P.: Development and Simulation of Solar Photovoltaic Model using Matlab/Simulink and its Parameter Extraction, ICCCE 2012, 12 and 13 Apr 2012.

15] ELGENDY, M. A.-ZAHAWI, B.-ATKINSON, D. J. : Assessment of Perturb and Observe MPPT Algorithm Implementation Techniques for PV Pumping Applications, IEEE Transactions on Sustainable Energy 3 No. 1 (Jan 2012).

16] ZAINUDIN, H. N.-MEKHILEF, S.: Comparison Study of Maximum Power Point Tracker Techniques for PV Systems, MEPCON-10, Cairo University, Egypt, Dec 19-21, 2010, Paper ID 278.

[17] AMJADI, Z.-WILliamSON, S. S.: Prototype Design and Controller Implementation for a Battery-Ultracapacitor Hybrid Electric Vehicle Energy Storage System, IEEE Transactions On Smart Grid 3 No. 1 (Mar 2012).

Received 25 February 2013

Govindasamy Sundar has obtained his BE degree from Madras University, Chennai in the year 2001. He obtained his ME degree from SCSVMV University, Kanchipuram in the year 2005. He received his $\mathrm{PhD}$ degree in Power system from Bharath Institute of Higher Education and Research (BIHER) University, Chennai, India. His research interest in the area of Power quality improvement using FACTS devices.

Narashiman Karthick currently, pursuing ME degree in Power systems Engineering at Arulmigu Meenakshi Amman College of Engineering, Kanchipuram from Anna University, Chennai.

Sasi Rama Reddy is Professor of Electrical Department Jerusalem Engineering College, Chennai. He obtained his DEE from SMVM Polytechnic, Tanuku, AP AMIE in Electrical Engg from institution of Engineers (India), M.E in Power System Anna University. He received $\mathrm{PhD}$ degree in the area of Resonant Converters from College of Engineering, Anna University, Chennai. He has published over 20 Technical papers in National and International Conference proceeding/Journals. He has secured AMIE Institution Gold medal for obtaining higher marks. He has secured AIMO best project awards. He has worked in Tata Consulting Engineers, Bangalore and Anna University, Chennai. His research interest is in the area of resonant converter, VLSI and Solid State drives. He is a life member of Institution of Engineers (India), Indian Society for India and Society of Power Engineers. He is a fellow of Institution of Electronics and telecommunication Engineers (India). He has published books on Power Electronics and Solid State circuits.

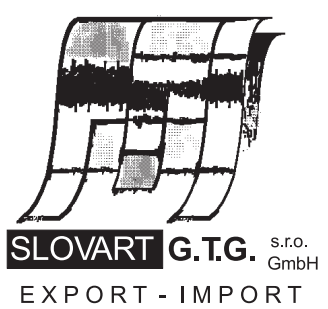

EXPORT - IMPORT
EXPORT - I M P OR T

of periodicals and of non-periodically printed matters, books and CD-ROMs

Krupinská 4 PO BOX 152, 85299 Bratislava 5, Slovakia tel: ++421 263839 472-3, fax: ++421263839485 info@slovart-gtg.sk; http://www.slovart-gtg.sk

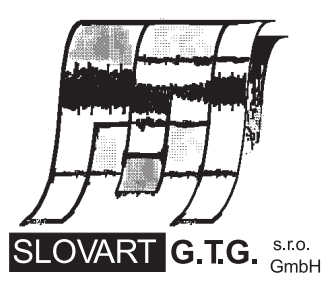

EXPORT - IMPORT 